\title{
Exploring Cooperatives, Cooperation, and the Nature of Work in a Belizean Village
}

\author{
Andrew J. Gordon \\ Anthropology Program, Department of Comparative Cultural Studies, University of Houston, TX
}

\begin{abstract}
This article examines how cultural models in the national political culture played out in a Belizean village whose culture was rooted in a quite different cultural model and characterized by ideals of self-reliance and individualism rooted in Yucatecan Maya culture. This is a study of eight worker cooperatives, of cooperation, and of individual work over a 34-year period, from 1979 to 2012 in the village of Bullet Tree Falls. This village is an historically agricultural village populated with Maya refugees from Mexico and Guatemala. I observed three distinct national political cultures, each seeking to promote local worker cooperatives. But generally, the national political culture did little to support the worker cooperatives. Only in the last phase of influence do we see what was necessary to make a worker cooperative organization somewhat functional. The paper concludes with observation of two enterprises where workers successfully participated, but not according to the formula for the cooperative. Here personnel could work independently but cooperated only when it proved useful. Recognition of positive features of the workplace environment suggests that investigating local cultural experience is an important and practicable effort, far more so than simply assuming the national political culture is viable on the local level.
\end{abstract}

Key Words: Maya, Belize cooperatives, national political culture, cooperation

\section{Introduction}

Villagers in Bullet Tree Falls, Belize where I conducted ethnographic research viewed their failures in worker cooperatives as reflecting something missing on their part. They view what they saw as their missteps: how they willingly took international aid, money and materials, but afterwards failed to follow through in cooperative work.

Administrators in the Belizean government's Department of Cooperatives saw the same problem. The acting director of the Department of Cooperatives read me an excerpt from a government document that reported only 15 worker cooperatives remained of the 215 that had started 34 years earlier. Another Belizean working as a United Nations consultant reported similar bad news. He wrote the following:

Of the 135 agricultural cooperatives registered in the country, $40 \%$ (53) are in the process of being liquidated or have been dissolved. The balance of the 82 societies is either dormant or semi-active and working, $10 \%$ of those agricultural cooperatives are active and working (Lisbey, 2008, pp. 3-4)

Another administrator in the Department of Cooperatives pondered about the government's first foray in agricultural cooperatives, the San Miguel Cooperative in Bullet Tree Falls. He just could not understand how San Miguel failed, when so many provisions by the national government suggested success: substantial funding, fertile land, available seeds, technical assistance, and all the necessary tools for farming. I, too, was surprised by the lack of progress in 34 years of experience. Surely there was alearning curve, I thought, where problems would be identified and resolved. I wondered why the problems had not been cleared up and resolved at an earlier point.

After doing the research, I found that the problems were rooted in impositions from the national political culture and the cultural resistance at the local level. I undertook to look at worker cooperatives to find out the roots of the cultural clash, to explore why and how the village responded as it did, and to learn what could be done to avoid failure in the future. To describe the influence of the national level, I rely on the concept of "political culture" (Almond, 1993; Aronoff, 2001; Aronoff \& Kubik, 2013; Lewellen, 1993; Pye, 1991) which signifies the attitudes, discourses, and institutions articulated by those in political power.

*Corresponding author: Andrew J. Gordon, Ph.D. Department of Comparative Cultural Studies, University of Houston, TX. Email: ajgordon@central.uh.edu

(c) This article is distributed under the terms of the Creative Commons Attribution License, which permits unrestricted use and redistribution provided that the original author and source are credited. 
To analyze national political culture, I rely on the concept of a cultural model within the realm of political culture. The concept is sufficiently embracing so it will cover scripts, plans and scenarios. The model in this context is close to what cognitive anthropology describes as master schema, which guide other minor schema as are found in scripts, plans, and scenarios (Casson, 1983; D'Andrade, 1992, 1995; Gordon, 2000; Quinn, 2003; Strauss, 1992). While maybe appropriate for a more precise analysis, the language of schema theory, with master schema, perhaps even metaschema paralleling metanarratives (Gordon, 2000: Lyotard, 1979,) here may well prove cumbersome and somewhat pedantic so I decided to simply use the concept of model as an orientation which drives thoughts and action.

First, I review the national political culture full of the ideals of Catholic social justice; among them: worker rights, human dignity, and care of the poor and vulnerable. The ideals were articulated by activists in the Belizean independence movement, from the 1940s up to 1984. Activists fought for independence of British Honduras, the colonial name for Belize until 1973. Also, they emphasized the need to redistribute wealth and what they viewed as a decent life for those who were colonized. Then from 1984-1989, we see another national model which extolled the importance of competition, privatization, and the promotion of business interests. Following this, a third model became important; it stressed the promotion of international tourism, launched since the mid to late 1980s and continuing until today.

In the village we find one cultural model relevant to worker cooperatives throughout the cooperative movement. Residents of Bullet Tree Falls followed the Maya cultural model of xieben, a Yucatecan Maya word meaning self-reliance and self-sufficiency, directly translated as "we are reliant and selfsufficient." There was an obvious clash between models from the national political culture and the village. The expression of xieben demonstrates the difficulties of imposing national cultural models. Then, I review my findings stressing the importance of identifying what, in the village, may predict success.

\section{Cooperatives, the Study Site, and the Methods of Research}

The worker cooperative movement started in the mid1800s in England with the Rochedale Cooperative (Shaffer, 1999). It was not until the 1960s and '70s that cooperatives became an important tool for economic development. Then, development planners imagined cooperatives as an economic arrangement which might satisfy the needs for ownership in economically marginal populations. Overall, national welfare would be enhanced (Develtere, 1993, 1998; Wasserstrom, 1988).

As expressed in a planning document from the United States, worker cooperatives are "consistent with the broad purposes of U.S. foreign aid: to help other countries to grow on their own, to improve the living standards of the people, and to strengthen their freedom and independence" (United States, 1967, p. 1). The worker cooperatives in Bullet Tree Falls were focused on economic development and collaboration. There were varied efforts in agriculture, retail, and artisan cooperatives. A distinctive feature of the cooperatives in the village was the support for individual work alongside cooperative efforts. For instance, in agricultural cooperatives, workers had individual farms contiguous to cooperatively-worked plots; and in artisan cooperatives, workers could create artisan work but their efforts were made within a cooperative structure dictating necessary contributions and participation. Despite this personal freedom, workers were uncomfortable with the norms of the cooperative where all work need be aligned with established sale prices, consensual decisions about production, sharing of materials and accepting elected leaders. The problems of the cooperative workers and their habits will be explored here.

Belize is a small country with a population of 367,000 in an area of 8,677 square miles. Although situated in Central America, many consider Belize a Caribbean nation. Belize is a member of the Caribbean Community and Common Market (CARICOM), not the Central American Free Trade Organization (CAFTA). The majority of the country had been populated by descendants of African slaves from Jamaica brought to Belize to cut down the logwood and mahogany forests during the 18th and 19th centuries, by Maya who are indigenous to the area, by British who originally colonized the country and by Euro-American settlers recently arrived looking for their tropical escape.

The nation is officially English speaking, with many of its governmental activities having been directed out of Kingston, the capital of Jamaica. Its music is Caribbean, first dominated by calypso and then by reggae, and now reggaetón. A favored food found throughout the Caribbean not in most of the rest of Central America, is the "rice and beans" plate of Belize.

Bullet Tree Falls is located midway on a northsouth axis extending from Guatemala in the south and Mexico in the north. The village is historically agricultural and populated almost entirely by Yucatecan Maya descendants who migrated from Mexico and Guatemala in the late 19th and early 20th century, escaping war in Mexico and politically 
oppressive governments in Guatemala. By 2012 the village of Bullet Tree Falls had a population of 3,400, an increase from 400 in 1960.

My study in Bullet Tree Falls covered six months of a sabbatical from my teaching position at the University of Houston in 2009 and spanning another 12 months from 2010 to 2012. Research on worker cooperatives meant using conventional ethnographic methods of open-ended interviewing, often capturing oral history. Additionally, I participated in the life of villagers and, as well, I observed cooperative activities. Also, I read private and governmental archives and interviewed key staff in government and in private concerns in Belize and in Canada.

My study on cooperatives was one of four segments of field research that examined the global influences on the life and culture of the village. The other three influences were the Rastafarian faith from Jamaica, the evangelical movement from U.S. missionaries, and the presence of cultural heritage tourism inspired by an American archeologist. I concentrated on cooperatives during my first stretch of fieldwork, in six months of my sabbatical. I had compiled lists of members from eight cooperatives and sought to interview each member about their perceptions and experiences of being in a cooperative, the successes and failure of the cooperative work, and the attitudes and values of workers outside the cooperative movement.

I found that the problems in cooperatives were pretty much the same in the three successive national political cultures.

The problems were mainly the workers' dissonance and distance from the national political culture along with a continuing negligence about cooperative work, and a distrust for their elected leadership. Only in the last phase of cooperatives, where revival of traditional crafts was prized, was there an absence of rampant stealing and a few who proved truly dedicated to the cooperative mission.

Not everyone who was a member of a cooperative was reachable in the first six months. I had three more years of field research dedicated to the other forces of globalization-Rastafarians, Evangelical missionaries, and the movement of cultural heritage tourism - and during this time I was able to contact others in cooperatives who I did not reach in the first six months of my fieldwork. Towards the end of my research in 2012 I applied the same method of open-ended indepth interviewing with workers in two organizations where cooperation existed, but the organization was run like a business, certainly hierarchical with decisions made by the founder of the organization. Here, too, I explored perceptions, attitudes, and motivations that belonged to the individual workers and to the entire organization. My examination of these two organizations plus reflection of the last phase of the cooperatives led me to realizations about what was necessary for local organizations to operate and what may contribute to local economic development. I share these reflections at the end of the paper.

\section{The First National Political Culture, Catholic Social Justice}

In Belize City of the 1940s, there was an emergence of a circle of writers, thinkers and discussion groups whose political energy led the way to an independence movement and independence in 1981. They were imbued with ideas of Catholic social justice promoted by teaching staff at St. Johns College, the prestigious Catholic high school in the country, where many were of this activist group had studied. They were members of varied associations in the 1940s and '50s: the Christian Social Action Group, the General Workers Union, a literary journal called the Mangrove, and a newspaper called The Billboard. The Christian Social Action Group proposed a winning candidate for the Belize Town Board Election in 1941. This group later gave birth in 1950 to the political party known as the People's United Party (PUP). George Price became president of the PUP in 1956 and stayed in control until 1992. Price was deeply influenced by Pope Leo XIII's (1810-1903) papal encyclical Rerum Novarum. which railed against an exploitative capitalism of 19th Century Europe (Grant, 1976; Shoman 1979, 2000; Smith, 2011).

Price, when premier of Belize. appointed Assad Shoman, a young socialist PUP lawyer to be Minister of Health, Housing, and Cooperatives in 1979. Shoman had recently returned from England where he studied law. While in England, he was imbued with the "spirit of 68" and its revolutionary fervor. He brought the spirit back to Belize and it informed his political identity as a socialist. In 1979, he started the cooperative movement, launching two agricultural worker cooperatives in Bullet Tree Falls: The San Miguel Cooperative and the Bullet Tree Livestock Cooperative, each with about fifteen members. Promoting the development of cooperatives was fully consistent with the PUP value of a "MIXED ECONOMY [emphasis in original], in which the public sector works in partnership with the private sectors" (PUP, 1979, p.1). By joining a cooperative, villagers received a title to land, financial support and assistance from the government and international sources with the expectation that workers would conform to the expectations associated with cooperatives.

A second stream of influence derived from Catholic social justice in the Coady Institute at St. 
Francis Xavier University (Saint FX) in Nova Scotia. The Coady Institute was set up to develop cooperatives internationally. With support from the Canadian government, the Coady Institute hosted Belizeans to a the Coady Institute. From 1963 to 1979 The Institute provided residencies for six weeks to six months. Then, between 1984 and 1988 Coady staff conducted 127 educational weekend sessions on cooperative principles which were attended by 3,277 Belizeans, most them in civil service (Landry, 1988). The Coady Institute emulated the thinking of Moses Coady at St. FX. Coady's ideas were encapsulated when he cited Pope Pius XI's (1857-1939) Papal Encyclical, the Quadragesimo, celebrating the $40^{\text {th }}$ anniversary of the Rerum Novarum. Coady cited the following passage:

Immense power and despotic economic domination is concentrated in the hands of a few. This power becomes irresistible when exercised by those who, because they hold and control money, can govern credit and determine its allotment....Free competition is dead; economic dictatorship takes its place. The whole economic life has become hard, cruel and relentless in a ghostly measure. (Laidlaw, 1971, p. 128)

\section{The Cooperative's Response to the First National Political Culture}

As a response to the inauguration of the cooperatives of Bullet Tree Falls. villagers were imbued with a spirit of togetherness and spirituality from Catholic social justice. They heralded a new order delivering them from oppressive poverty. The vision of a new type of society was expressed in the Solidarity Concerts in the village from 1978 to 1981. Music and songs voiced appreciation of their work, their religious faith, and their hope for Belize's eventual independence. The Catholic religious dimension of the concerts was reinforced by the participation of Carlos Godoy, a singer and troubadour for the movement of the socialist Nicaraguan Sandinistas and Liberation Theology in the 1970s. Also, in 1983 the San Miguel Cooperative held a three-week workshop, a mix of instructional workshops and gatherings where participants got together to express their hope for new social order (Gordon, 2017, pp 59-60; San Miguel, 1983).

However, instead of maintaining this cooperative spirit, villagers reverted to the cultural model of xieben quite the opposite of the ideals of cooperative life. Members of the cooperatives reflected the xieben of the owners of milpas, small plots of land for family farming, tended for two or three seasons and then left to lie fallow for several years. Milperos (owners of milpas) are proud of the way they do farm work and tend to their families. Villagers valued themselves as disciplined, hard-working, and persevering (Lambert \& Arnason, 1982; Moore \& Stanley, 2004; Nutini, 1976; Reina, 1967; Sullivan, 1978). I frequently heard the phrase buen milpero ("good milpa farmer") as a compliment for men knowledgeable in farming, one who could take care of himself and his family. They were proud of their knowledge about planting and timing for planting, the preferred phase of the moon to plant certain crops, the best seeds to be used, and they stressed the need for steady, disciplined work habits. If the milpero was in his seventies, then observation of the milpero was somewhat reverent, even more so if the farmer was in his eighties or nineties. Farmers bragged about never missing a day of work on their milpa, about rising at 5 or 6 a.m., returning home at 11 a.m. in the heat of day for lunch and rest, and then putting in more hours of work in the afternoon. These farmers clearly had no need for any cooperative decision-making. The idea self-reliance and the value on self-sufficiency were not simply the preserve of men; women revered the same ideal as they did all necessary to manage the home and the need to make clothes and food, and to tend to other household responsibilities.

Xieben overrode any tendency to be cooperative. The sensibility of individual responsibility and individualism was strengthened by economic changes. Residents were making a transition from an economy based on near-subsistence farming to a money-driven system (Gregory, 1987). Cash became very important; to pay for water, electricity, store-bought clothes, and children's schooling. To make extra cash, cooperative members looked for temporary jobs all over the country, usually in construction or tourism. While cooperative workers were away, their cousins or other relatives filled in for them on the cooperative.

Never before had villagers been recipients of such largesse from their government. They were far from grateful, however; perhaps even resentful about the loss of personal responsibility. Some workers were apparently cynical and self-serving as they pilfered and sold tools and the farm equipment supplied to them. Additionally, cooperative members took advantage of the loan program. The Belizean government encouraged the farmers to take out loans to promote investment in agricultural enterprise. Those taking out loans used a portion of the cooperative as collateral. However, the loans were used for luxury items, such as television sets, in anticipation of the day when the town would have its own electrical grid. Typically, they did not pay back the loans. The PUP government, fearing the loss of political support, did not press for repayment.

The cooperative presented a wholly foreign way of doing things; it made no sense to them. Workers 
had little incentive to work with one another or to participate in common decisions about what to plant or what the sale price would be. Farmers appeared to have viewed the cooperative as an opportunity to relax and enjoy themselves, like moments in the past after they sold their harvested crops from the milpa. With money in their pocket from the harvest, farmers often headed for the bars; they took a "time out," a term used to describe their temporary escape from responsibility, usually aided by excessive drinking (MacAndrew \& Edgerton, 1969).

I found that San Miguel Cooperative members treated their farm as a leisure zone, not a site of work. After years of hard work prior to joining a cooperative, Don Capo Martinez believed that he led the "good life" as a member of the San Miguel Cooperative. He left home on his horse early Monday mornings at dawn, well-provisioned for five days with easy-tocarry items such as tortillas and beans. Two and a half hours later, he arrived at the cooperative to work until Friday. He regarded his life at the cooperative as a "luxury." Don Capo reported that his fellow cooperative members had access to fertile land, a creek for bathing, and a more comfortable climate at a higher altitude, a place where they all could enjoy long walks.

Members of the Bullet Tree Livestock Cooperative, the other cooperative of the first of the movement, were equally as disinterested; not all engaged in their common enterprise of raising cattle. They were even careless about cleaning the impoundments containing water for cattle. One account illustrates the general lack of commitment. Suddenly and quite mysteriously, a cow dropped dead in 1983. Veterinarians from the Department of Agriculture came to investigate. They found that a cow had fallen victim to a highly contagious worm infestation likely to spread to other cows and kill off the entire herd. Because of this, the veterinarians recommended the inoculation of other cows. All the veterinarians needed was one member of the cooperative to sign a note regarding the cooperative's intention to cover the cost of the inoculations. No one wanted to sign; no one seemed to care. Feeling professionally responsible for the welfare of the cows, the veterinarians went ahead and inoculated anyway. ${ }^{1}$ Later that same year, four members of the Bullet Tree Livestock Cooperative resigned, claiming they had lost confidence in the whole cooperative enterprise and describing the management as "rotten." None had any desire to work towards common goals or associate with each other. In 1984, the president of the Livestock Cooperative assessed the situation as unsalvageable and dissolved the cooperative. ${ }^{2}$

Also, workers were simply unresponsive to the leadership in the cooperatives. Villagers had no experience with an authority, being only exposed to the elected leadership of mayor of their village (the alcalde). The mayor's scope of authority was limited, mostly limited to organizing faenas or village cleanups and in keeping order during the fiesta patronales, the parties that honoured the village's guardian saints. While the elected presidents of cooperatives should have been able to exhort the efforts of the cooperative workers, the presidents just could not command any respect, just by being elected. The deck was stacked against the presidents. Qualities that made someone electable were the same qualities that made him untrustworthy and suspicious. Positive features of the prospective president making him electable such as being literate and articulate, good with numbers, and comfortable in meetings with government authorities made those electing the president feel suspicious of the person they elected. Workers imagined that the presidents would use their capacities and connections to embezzle funds. Many described their leaders as listo, meaning "ready and aware," readily disposed to take advantage in any financial dealings.

Simply put, adhering to collective activities was not the way of the villager. Neither the San Miguel Cooperative nor the Bullet Tree Livestock Cooperative was no longer functional after six years. The San Miguel Cooperative warehouse burned down after five years because of a suspected arson to hide a theft. The Bullet Tree Livestock just folded with a discouraged group of workers. Early expressions of unity and collective aspirations were well-meaning, but very short-lived.

\section{The Second National Political Culture, Being Business-Minded}

The principles of Catholic social justice and a redistributive economy to guide the cooperatives became a thing of the past. The conservative party opposed to the PUP, the United Democratic Party (UDP) trounced the PUP and George Price in national elections. Manuel Esquivel of the UDP emerged as prime minister and a new national political culture took over.

Before the election, Price was losing favor due to widespread suspicion. Belizeans were uncomfortable with Price's friendship with Fidel Castro and Omar Torrijos, both much too far to the left. Plus, the country suffered an economic downturn that made Price look bad. Bullet Tree Falls villagers grew especially skeptical when the government made optimistic projections. The Marketing Board had counseled farmers that 1981 would be a great year for the corn market. Somewhat a novice at his work, the director of the Marketing Board was flat out wrong. A worldwide glut for corn happened. with a 30 percent decline in world corn prices (CME Staff, 2017). 
Cooperative members and individual farmers had corn rotting in their fields.

Esquivel was in sync with a worldwide turn to the right, which also included Ronald Reagan's election as president of the United States in 1981, an election in Canada when conservative Brian Mulroney became prime minister in 1984, and conservative Margaret Thatcher who was prime minister in the UK in 1979 (Savoie, 1994). When Esquivel was prime minister, he had a friend in Washington: the U.S. Embassy staff in Belize jumped from seven employees to forty-seven. The United States Agency for International Development allocated US $\$ 60$ million to development projects (Shoman, 2000).

When the UDP came on board, everyone was expected to be business-minded. Nevertheless, conservative Canada was on board in the cooperative development, at least they appeared to be (Gordon 2017, pp. 54-83). Certainly, the cooperatives were antithetical to the business model, but the conservative agenda was realized anyway. When Mulroney of Canada was in charge along with like-minded Manuel Esquivel, there was no more direct assistance coming from Canada to Belize. ${ }^{3}$ An ethic of private ownership took over and government functions were outsourced to non-governmental organizations. Canada ostensibly invested in international assistance which was effectively building up opportunities for enterprise (Blanchette, 1994; Burdette, 1991; Eden \& Molot, 1993; Rudner, 1991; Savoie, 1994; Taras, 1985).

Canadian assistance to cooperatives was channeled through programs that built up private enterprise. The funds from the national government's Canadian International Development Association) went to a private non-governmental organizations (NGOs), the Canadian Co-operative Association (CCA). Then funding from the CCA to Belize was not to a government but to Belizean private, nongovernmental organizations and the plan of outsourcing, not relying on the national government, was imposed on Belize.

\section{The Response to the Second National Political Culture}

The business-like way of doing things with Esquivel and Mulroney heightened acquisitiveness in the cooperative set-up. Every three years, starting in 1984, the Canadian government turned over about four million dollars to the Canadian Cooperative Association. ${ }^{4}$ In this political culture, international assistance was preferably outsourced to non-profit enterprises in Belize. Once the CCA was funded they, in turn, funded two new non-governmental organizations in Belize to supervise the cooperative movement, making the number it three in total for
NGOs involved with cooperatives. No longer was direct government assistance to another government to promote development. The push for privatization extended into Belize.

Once the Canadians got involved, the San Miguel cooperative was flooded with investments of agricultural machinery, tools and a storage unit. But it all disappeared. The level of theft was proportional to increased levels of assistance.

Michael Rosberg, once a principal player at CCA responsible for cooperatives in Belize, wrote a book, The Power of Greed, drawing on his experiences in Belize. He reflected on the way that tieving, the creole word for thieving, had become a social norm (Rosberg, 2005). The tendency toward tieving grew ferociously with Canadian assistance in Bullet Tree Falls. In the San Miguel Cooperative, they no longer just stole tools; they stripped down a donated tractor and sold it piecemeal - wheels, radiator, alternator, and the engine - they sold it all. Michael Rosberg, 29 years after writing his book reflected to me:

It's kinda embarrassing to look at my innocent self. In a real way, it was partly the failure of the Belize work that gave birth to The Power of Greed (2005). There was anything but collective action in Cayo and the way we designed our interventions contributed greatly to the failure of NGOs. We encountered much talk of cooperation and appealed to folk's better natures. Alas, we forgot they were also capable of great opportunism and self-serving behaviors as actors competed for scarce resources. I'm afraid we set them up for intensified competition by dangling resources and exacting little accountability. ${ }^{5}$

In 1985, a year after Canadian assistance began, the president of San Miguel, Don Capo, reflected on tieving and other problems. He wrote a memo to the Department of Agriculture complaining of the problems in the cooperative: a rash of thefts; farmers selling crops independently rather than selling collectively at a fixed price; using the storage facility to hide marijuana; and otherwise demonstrating a low level of commitment to the cooperative venture. Yet, the president who wrote this memo was no different. One night, he confessed to me that he was active in fletes, renting the tractor and other equipment to nearby farmers.

The situation in the Bullet Tree Livestock Cooperative was no better, worse in fact. The CCA stepped in with Michael Rosberg who sought to convert the livestock cooperative switching production from livestock to peanuts and grains. Members agreed that this emphasis would result in a successful cooperative that would "improve the standard of living socially, and economically."

However, the famers were little interested in harvesting crops; instead, they were very interested in 
harvesting loans that were minimally repaid. ${ }^{7}$ These loans included $\mathrm{BZ} \$ 62,000$ from the $\mathrm{CCA},{ }^{8} \mathrm{BZ}$ $\$ 35,000$ from the Small Farmer's Bank, and BZ $\$ 38,000$ from the Belize Federation of Agricultural Cooperatives. Only a small portion of the loans were collected, just the loaned amount from the Small Farmers Bank when they appropriated land that was held as collateral. ${ }^{9}$ The president of the Bullet Tree Livestock Cooperative acted like everyone else, even worse, since he was somewhat more brazen. He made off with BZ $\$ 10,000$ from the cooperative's treasury and disappeared into the United States. From 1987 to 1989, the cooperative continued without any meetings. ${ }^{10}$ When in 1989 the cooperative was "about to fall apart", members simply chose to dissolve the cooperative. ${ }^{11}$

The staffs in the Belizean NGOs were not at all helpful. The staffs seemed to follow the capitalist ethic of Mulroney and Esquivel. Within the three NGOs serving the cooperatives, they wound up fiercely competing with one another. Each NGO worked hard to secure the next foreign contract, not just from Canada but also from other international sources. The staff grew accustomed to the habit of doing all possible to ensure that their livelihood and workplace would survive and grow. They spent their time looking for the next grant, doing relevant research, making contacts and preparing proposals; there was little time for visiting cooperatives. They did not entirely absent themselves to find out about what was going on in the cooperatives, however, the approaches were superficial. To find out anything, the presidents came to NGO offices to meet as a group. The meetings with presidents did not get down to the real problems of theft and alienation. As might be expected, the presidents were slow to describe any difficulties that might prejudice their continued funding.

The CCA in Canada did made some attempts to get information. For instance, Rosberg told me he sought to investigate the situation at San Miguel. He was quite satisfied after observing a meeting of cooperative members. He reported that all was well. This positive assessment was not surprising as Rosberg was only exposed to a meeting of the cooperative at San Miguel, and the format of a meeting was such that workers were prepared to be on their best behavior. To find out what was going on in the cooperative, the CCA would need to have spent time on site and gain the confidence of some workers. Neither the CCA was inclined to do this additional information gathering, nor were the Belizean staff at the NGOs similarly inclined.

The Belizean government did not shy away from their business-like commitments to the NGOs. When there was a government contract pending for the import of Mexican foods, the federal government fixed it so the business of importing went to one of the NGOs, the Belize Federation of Agricultural Cooperatives. Also, the government directed government workers in the Department of Cooperatives and the Department of Agriculture to work in the NGOs alongside the staff. There was little separation between government and private enterprise. During the second phase of the influence of the conservative cultural model, the NGOs set up two retail cooperatives in Bullet Tree Falls. The retail cooperatives sought to sell villagers those items of everyday use like sugar and soap. Instead of running off to make purchase in the town of San Ignacio, three miles away, villagers could make local purchases. However, the initiative was subverted by the NGO staff commitments. Staff showed little interest in fomenting any cooperative ethos and activity. In fact, one NGO directed one retail group, La Tienda, to act as if they were subordinates to the NGO. The La Tienda Cooperative was directed to make their wholesale purchases from one vendor in San Ignacio. This wholesaler also happened to be the mother of the local UDP representative, an arrangement certainly favoring the political position of the NGO. While a search for a wholesaler might have been an opportunity for La Tienda personnel to learn the art of finding the best prices, the interests of the NGO took priority. Also, this NGO took on the responsibility for handling all financial records of $\mathrm{La}$ Tienda. Cooperative members never even saw a bank statement. The NGO went so far as to establish the rate of workers' pay: an arbitrary two dollars a day, a pay scale reflecting what NGO staff thought the workers should get, not reflecting the gains of the retail outlet.

The workers were not passive nor inclined to be simply victims. Member of the cooperative related that they acted on their own behalf. Cooperative members in La Tienda "borrowed" food and other products from the store's shelves, presumably with the intention of paying later. Also, those working the cash register were inclined to take a bit of money when needed. After five years the shelves were empty; no money was to be found in the till. Finally, the place burned down, another case of suspected arson. I learned from the president of the other retail cooperative, El Molino, that this enterprise did not fare any better, lasting just three years, but I was unable to get the same level of detail. The first president told me that it had only been a matter of a few months before she quit.

In the first era of Catholic social justice, the government personnel and political leaders presumed that the villagers were just like them: high-minded, given to democratic socialist ideals, and ready to be cooperative and egalitarian. In the second era, the 
cooperative worked in the fashion of the conservative political culture of Mulroney and Esquivel. Individualism was unbridled and unregulated. A wholly different way of acting started to show up in a third phase.

\section{The Third National Political Culture, Valuing Nature and Cultural Heritage}

The third phase of cooperative development started in the mid-1980s. The Belizean government promoted the natural environment and cultural patrimony to attract international tourists. Previously, tourism had been far from a priority. Price had exclaimed that tourism in Belize was "whorish" (Berendse, 2007). Then the UDP elevated tourism to a priority. Tourism in Belize went from a seventh-place contribution to the GDP to second-place over the course of a decade (Roessingh et al., 2008).

Caribbean tourism was the bedrock of economic development for newly independent countries of the Caribbean (Harrison, 2001; Modeste, 1994; Roessingh, 2008; Zappino, 2005). Growth in tourism was astounding. In thirty years, stayover arrivals in the Caribbean increased by 383 percent, from 4.2 million arrivals in 1970 to 20.3 million arrivals in 2000. The role of tourism was foreseen in 1966 by the Tripartite Economic Survey composed of Canada, the United Kingdom, and the United States. The report by them concluded that "tourism and light industry were ideally suited to the Caribbean [since they] were the type of labour-intensive industries on which the small islands of the Caribbean could base their economies" (Duval \& Wilkson, 2004).

In Belize, the tourism industry first established itself in the 1970s on the country's Gulf Coast when international tourism highlighted beach vacations, diving, and fishing. Then, by late 1980s tourism started to move to the interior of the country. Tourism ventures then emphasized ancient Maya culture and archaeological reconstruction of millennia-old pyramids, temples, priestly residences, and ball courts. In the 1980s, the Department of Archaeology had registered 700 Pre-Columbian sites, an average of one every thirteen square miles (Glaser \& Betancourt, 1989). Also, accessible to tourists were the Maya villages of Belize which provided visitors with local cuisine, marimba music, as well as artisanry in clothes, pottery, painting, jewelry, and sculpture. The natural world was also featured with tourism companies offering inner-tube trips down jungle rivers, zip-line tours, and up-close views of Belizean wildlife (Barry, 1995; Berl-Cawtran Consortium, 1984; Glaser-Kohler \& Betancourt, 1989).
The surge in tourism reached Bullet Tree Falls in 1944. Villagers were thrilled to take part in what seemed an unquestioned prosperity right around the corner. Then, American archaeologist Anabel Ford began excavation of a site 128-acre Maya city-state of El Pilar, which had reached its peak of development in the ancient Maya world more than a millennium ago. El Pilar is eight miles from Bullet Tree Falls and the village was to have been a "a gateway to El Pilar." It was anticipated that villagers were to make Maya artifacts, provide food and hospital access, and offer an opportunity for tourists to gaze on living culture. Ford also set aside a 2,000-acre nature reserve so that visitors might explore the forest as a resource where the Maya had always foraged and farmed, hunted and searched for herbal medicines and wood for building materials.

Tourism development reversed the PUP's position. In 2002, the then PUP Prime Minister Said Musa remarked in a public speech:

El Pilar brings together several innovative features on how we would like to see things [;] there is so much to be proud of [in] our past, in our history; the greater Mayan civilization is still very much alive in Belize. It is not dead stones and ruins, but rather temples that should inspire us, a civilization from which we can learn many things. Conservation blended with bringing ideas about development paves the way for all arguments of contradiction between environmental concerns and development. Preservation, environmental protection and economic development are to bring about a better life for the people of today and for future generations (Belize Times, p, 5, June 6, 2002).

\section{The Response to the Third National Political Culture}

At first, there was widespread local enthusiasm with Ford and the promise of tourism. However, exuberance about the future eventually turned into disappointment. A positive outlook about the future steadily lessened and turned into total disappointment. In 1995, villagers were not at all pleased with the prospect of turning over milpa land to a nature reserve established by Ford. Thirty-six farmers had to relinquish their milpa plots to create the nature reserve (Gordon, 2017). The acrimony between Ford and the community grew progressively more pronounced, as Ford was perceived as too bossy. She stopped work in the community in 2005 (Gordon, 2017, pp 22-33).

At this point, villagers were once again inspired to develop cooperatives, this time as an alternative to the development of tourist services. From Ford, villagers learned that funding of a project would be a good chance for economic development. Villagers 
were successful in winning funding in 2010 from the Canadian embassy, which had a program called the Canadian Fund for Local Initiatives. From this fund, villagers received BZ \$12,000 for an Organic Farmers Cooperative. From the European Union, villagers received BZ $\$ 25,000$ for a crafts cooperative, Women on the Move. From the Coordinating Association of Indigenous and Community Agroforestry (or in Spanish, Asociación Coordinadora Indígena y Campesina de Agroforestería Comunitaria Centroamericana), villagers received BZ \$ 25,000 fir the Sewing and Souvenirs Cooperative (Gordon, 2017, pp. 13-33). Despite the success in gaining funding, local features of their culture, expressed in xieben, eventually undermined the projects.

The responses in the cooperatives echoed the disengaged responses with the previous models of political culture. There was just not a lot of interest in working together in the cooperative framework. The nature of the problem was succinctly expressed by Luisa, the president of Women on the Move, who remarked

I am a chairperson and I don't know what to discuss with the group. The members don't help you, you know, and they say I must do my agenda for each meeting, and I really can't do it. They want to have a record of the agenda every meeting... And you can't do anything with just four or five members; the rest don't show up, ever...They take advantage of me, wanting me to go out and develop places to sell. We started as a group, but there is no group right now. ... Last time we had a meeting was the $15^{\text {th }}$ of March 2010 [15 months previously].

The other artisan cooperative, Sewing and Souvenirs, saw similarly a widespread disinterest; members just stopped showing up. The Organic Farmers group suffered the same fate as the other cooperatives. Initially, 11 individuals were eager to participate after receiving the grant, but merely five showed up for the initial training sessions. In the end, the president of the organic farmers was mostly alone, excepting the participation of his brother.

There was a difference in worker response in this phase. We do not see the level of theft that plagued cooperatives during the first two political cultures. The material of the artisan crafts cooperatives - the lathes, knives, pincers wires, pottery wheels and kilns of the crafts, and the agricultural equipment for organic farming — did not disappear. Perhaps theft was not an issue when cultural heritage was involved.

There were a few though who showed commitment to the work of the cooperative; their responses suggested a fruitful strategy for economic development. In their work they acted so to be congruent with the model of xieben, self-reliant and independent, yet they could contribute to the cooperative. They had the ability to carve out space and time and to work independently. These commitments to work came from the presidents of the cooperative. They were the ones who were deeply committed to cultural traditions and an appreciation of their cultural heritage. In the two artisan cooperatives, the presidents were Kekchi and Mopan Maya, coming from Maya groups where artisan traditions were still vigorous, unlike the village residents, mostly Yucatecans for whom artisan traditions had long been fading. The third president, the one presiding over the Organic Farmers, was Yucatecan and committed to revive Yucatecan traditions. He was a Mayan speaker and was eager to explore traditions of organic farming, historically part of Yucatecan life. Family members of these presidents were also eager to join in. Chabella, the president of the Sewing and Souvenirs Cooperative, was joined by her mother, a niece and a cousin all of whom came to use the cooperative's kiln, potter's wheel, and sewing machines. Luisa and her family all used what the Women on the Move workshop had to offer: vices, scissors, and pincers for sculpture and jewelry. The president of the Organic Farmers Cooperative was joined by his brother, weekly.

I saw no evidence of the presidents being distracted by ideology of the cooperative. Simply, the possibilities in the artisan workshops and on the organic farm afforded the opportunity of being involved in one's own work and depending on oneself. I did learn of two other organizations, the Beekeepers (the Abejeros) and the Chicken Farmers (the Polleros) that were successful and that identified themselves as cooperatives, but they were far from the model of how cooperatives were supposed to be. They had a boss in place and decision making did not come from consensus or an egalitarian ethos.

\section{Success in Cooperation: Two Organizations}

Despite mostly individual efforts of the workers had a good measure of cooperation, gathering periodically to help each other out using equipment and tools provided by their leader. Cooperation among the Beekeepers meant working together to refine and prepare their product for sale. They brought in their honeycombs to the organization's headquarters to help each other out. Together they extracted honey from the combs and filtered the honey. They weighed and bottling the product for their clients. There was a similar willingness to cooperate among Chicken Farmers. After having raised the birds to maturity and slaughtering them, the members - each with their own chicken coops - brought the slaughtered birds to the headquarters, at the boss's residence and prepared the birds for sale. Workers together addressed the task of 
de-feathering, cleaning, packaging and freezing the birds. One day, Doña Janette Manzanero might bring in 300 birds to be prepare for sale; on another day, Doña Betty Cruz might bring in her 200; and so forth. The experiences of these two organizations suggest that villagers were not opposed to cooperation as might exist in the cooperative organization. Simply, cooperation needed to be useful and directly connected to revenue, not to ideology. The attitudes of the Beekeepers and Chicken Farmers were like milperos; they could work unconcerned with the efforts of other; and they could be proud of their efforts. They fully expressed xieben. Chicken farmers working in chicken coops outside their homes and beekeepers tending their hives kept busy unconstrained by the codes of cooperatives marked by consensual decisionmaking or ostensible egalitarian relations.

These organizations, unlike cooperatives, had leaders and founders who recruited workers and encouraged their productivity. Although this was a hierarchy, workers were quite content being under the authority of others. The bosses, it turned out, were respectful, in a way that was unknown in cooperatives where presidents simply appeared to take advantage of others.

In the Beekeeper and Chicken Farmer organizations those who headed the organization knew how to bridge any dissonance with workers. Eduardo Espat, a co-founder of the Beekeepers, ran the group's meetings and he made it a point to be inclusive, to let workers have a voice in how things should be run. He would elicit suggestions from everyone and the mood was one of trust. I asked Espat how he happened to be so adept with people:

It comes from something we have developed by talking to people, by -I think we Espats [his family name] have a certain amount of judgment. We are used to sitting down with people and solving problems. People come to us all the time. At 89 [years of age] I am a commissioner of the Supreme Court; I am a Justice of the Peace still.

His brother, Don Gustavo Espat, was a co-leader of the beekeeper organization. He had a small grocery store, not a very lucrative business, but a place where he and visitors enjoyed themselves, chatting and passing the time. He was always relaxed and affable in his dealings with the membership of the beekeepers. Doña Sara Diaz, leader of the chicken farmers, was equally as agreeable. Members reported that she knew how to deal with others whose work she oversaw: being fair, praising contributions, setting rules, and correcting errors. If a member missed participating in the early-morning work session, became less interested, or arrived with birds that were of a less than adequate size, Doña Sara would encourage them to change their practices. If the workers continued to disappoint, she encouraged them to drop out of the group.

There was always a sense that their efforts would bring income. It was not like production in the artisan cooperatives where buyers were not to be counted on. Nor was it like farming where a worldwide glut could depress prices.

Eduardo Espat secured buyers for honey after having visited consulates from France and Germany in Belize's capital. Also, he secured international development assistance funds to purchase materials necessary for honey production. His brother Gustavo was the one who was competent in honey production. He passed onto workers all that he had gained through the study of beekeeping at Ohio University, on a fellowship financed by the United States Agency for International Development. Gustavo was sure to visit the hives developed by the members, and he instructed participants about hygiene and the use of antibiotics and pesticides, all necessary for generous honeycombs. Doña Sara of the chicken farmers contacted points of sale, the restaurants and retail outlets where the birds were delivered to consumers. Additionally, she was aided by her son-in-law, Niles Samuels, who provided instruction about hygiene, feeding, and staying alert to any signs of infection. He offered tips about 24-hour lighting all promoting faster growth of the chickens. Samuels arranged a system wherein each member started with 50 chickens, then moved up to 100 , then several hundred, until eventually reaching a maximum of 700 . This gradual approach allowed members to absorb a steady but not overwhelming flow of new information and experience. There were no suspicions about leading authorities, the presidents, wanting to take a greater share for themselves. Workers already accepted inequality and there was no problem in hierarchy. Hierarchy and privilege were simply expected.

Beekeepers and chicken farmers could be individualistic and ambitious; they could work as much they chose, make money and satisfy a desire to enrich themselves. They had ways of working very much prized in the Esquivel and Mulroney era. There was nothing distinctly Maya about the work of beekeepers and chicken farmers and any misrepresentation about the importance of cultural affiliation would not be appropriate. Essentially, work was accomplished where individuals on their own and with their own volition, could get the job done. The key to success lay in the ability to just be involved in one's own efforts.

The Beekeepers were in existence from 1981 until 1988, at which time the U.S. government sprayed paraquat in all areas of the country where marijuana might be grown. Paraquat destroyed not only the production of marijuana but also the flowers, the source of food for the bees, and, consequently the honey 
industry (Sutherland, 1998). The other successful enterprise, the Chicken Farmers continued from 1984 until 2001, when competing chicken farmers employed machinery that did the work more cheaply. Both the Beekeepers and Chicken Farmers lasted and were successful because they were consistent with local cultural norms of personal independence and selfreliance.

\section{Conclusions}

In viewing these successes, we arrive at two important lessons to impart. First, we see how work is motivated and organizations may triumph by allowing and promoting personal commitment and self-reliance. Conditions maximally satisfying for work are established and they thrive in the absence of preoccupations of management styles propounded by one or another version of national political culture. This observation may cause one to question if a rigorous adherence to norms of cooperatives is always the best route. Perhaps, inducing more cooperation in a business model might be the answer.

Second, it would surely be better if the national political culture was given to unearth the important features of worker behavior, without launching a program less than aware of local cultural model. If the leaders in the national political culture are open to alternative models (like the Maya xieben), then strategies for success may well come to light. Then, strategies for local organizations may be identified and remain unfettered by a need to simply conform to the national political culture. Apparently, the attention from the national political culture - first the Catholic social justice ideals, then the business model, and finally the expression of ethnic culture-just did not fit in with the village. But it is not simply a Maya model which may prove resistant to national political culture. In Belize, we find other cultural models, in Garifuna culture, in African-American sectors, in what are defined as Creole populations, or models may come from people involved in other processes of production, such as fishermen or factory workers. It will not always be xieben; the local cultural model may have other origins and expressions. A critical inclination is to know about the cultural models of a locality before imposing a design cooked up at the national level.

A word about culture models and the national political culture is in order. When developing economically sound programs for members of a local culture, the architects on the national level may well be inclined to confuse their goals and modus operandi with those on the local level. This happened again and again in the village, as we have seen. Thus, the problem in cooperatives is not a matter of the villagers falling short of the expectations. It is a failure of national authorities to understand what can feasibly take place. The national culture needs to be open to alternative local realities and not assume that their way is the best way for others. This means, and it is a most challenging task, those who take part in the national culture need be aware of their own inclination to think their own cultural models are the best and only solution for others.

\section{Notes}

1. Memo from Bertram Enriquez to Registrar of Cooperative, February 14, 1984, Central Falls Archive.

2. Minutes, Bullet Tree Falls Livestock Society meeting, June 11, 1984, Central Falls Archive.

3. With Trudeau as Prime Minister Canadian government had provided Belize with $\$ 32$ million Canadian dollars for a sewage system in Belize City and in 1982, \$2 million Canadian dollars for the construction of grain silos in 1982 The amount for this grain storage project was CA \$2,559,110, Project \# 010158. WBS number 010158001. For the sewage project, there were three stages: Stage I (WBS number A0101001) of this project finished in 1982/1983 starting in State I 1975 with a cost CA $\$ 10,667,551$; and in Stage II (WBS number A01097001) of this project from the 1982/1983-year cast CA \$25,077,448 until 1993/1994 and in Stage II (WBS number A01097001) of this project from the 1982/1983-year cast CA\$ 25,077,448 until 1993/1994. (Page one of the document Grain Storage Regarding the Arrangement between Her Majesty the Queen Represented by the Secretary of State for Foreign Affairs and Technology Ltd. St. Laurent Quebec, a consultant. LAC, nd.)

4. A little more four million for three year block grants went to the CCA from the Canadian International Development Association. The funds went for work in about 20 countries and the total bill of the program was for 13 million Canadian dollars for a nine year period. About CA $\$ 150,000$ to CA \$ 250,000 went to Belize per year. Recorded at the Canadian Cooperative Association Oct. $12^{\text {th }} 2011$.

5. Email communication from Michael Rosberg on July 15, 2011.

6. February 6, 1985, letter to Michael Rosberg from Telesforo Tsib, Central Falls Archive.

7. Letter from Hugo Miranda to Registrar of Cooperatives and Credit Unions, April 19, 1999, Central Falls Archive.

8. Confirmation of Transmittal of monies from the CUC to the Cooperative Society, March 15, 1985, Central Falls Archive.

9. Letter from Ernesto Pech to managing committee for the Bullet Tree Farmers, March 30, 1993, Central Falls Archive.

10. Letter to Keith Wright from Isabel Cocom and Ponciano Cok, March 28, 1989, Central Falls Archive.

11. Memo from J. M. Haddad memo to registrar of cooperatives, 4 March 1991, Central Falls Archive. 


\section{References}

Almond, G. (1994). Foreward: A return to political culture. In L. Diamond, Political culture and democracy in developing countries, pp. ix-xii. Boulder, CO: Lynne Rienner.

Aronoff, M. (2001). Political culture. In N. J. Smelser \& P. B. Baltes (Eds.), International encyclopedia of the social and behavior sciences, volume 17 (pp. 1164011644). Oxford, UK: Elsevier Science.

Aronoff, M., \& Kubik, J. (2013). Anthropology and political science: A convergent approach. New York, NY: Berghahn.

Barry, T., \& Vernon, D. (1995). Inside Belize (2nd ed.). Albuquerque, NM: The Interhemispheric Resource Center.

Berendse, M., \& Roessingh, C. (2007). Hidden and unspoiled: Image building in the tourism industry of Belize. International Journal of Tourism Policy, 1(3), 267-282.

Berl-Cawtran Consortium. (1984). Tourism development 1984-1990: Strategy and action plan. Belmopan, Belize: Belize Archives Department.

Blanchette, A. (1994). Canadian foreign policy, 1977-1992. Selected speeches and documents. Ottawa, Canada: Carleton University Library.

Burdette, M. (1994). Structural adjustment and Canadian aid policy. In C. Pratt (Ed.), Canadian international development assistance policies: An appraisal. Montreal, Canada: MQUP.

Casson, R. W. (1983). Schemata in cognitive anthropology. Annual Review of Anthropology, 12, 429-462.

CME Staff. (2017). Corn historical prices charts-historical commodity futures charts: CBOT. Trading Charts / TFC Commodity Charts. Chicago, IL: Mercantile Exchange. Retrieved from http://futures.tradingcharts. com/historical/CN/1981/0/continuous.html

D'Andrade, R. G. (1992). Schemas and motivation. In R. G. D'Andrade \& C. Strauss (Eds.), Human motives and cultural models (pp, 23-44). Cambridge, UK: Cambridge University Press.

D'Andrade, R. G. (1995). The development of cognitive anthropology. Cambridge, UK: Cambridge University Press.

Delvetere, P. (1993). Cooperative movements in developing countries old and new orientations. Annals of Public and Cooperative Economics, 64(2), 179-208.

Delvetere, P. (1998). Cooperatives in the Caribbean a cooperative movement: The history of the cooperative movement. Port-of-Spain, Trinidad: Trinidad Government.

Duvall, T. D., \& P. F. Wilkinson. (2004). Tourism development in the Caribbean: Meaning and influences. In D. Timothy (Ed.), Tourism in the Caribbean (pp. 59-80). London, UK: Routledge.

Eden, L., \& Molot, M. (1993). Canada's national policies: Reflections on 125 Years. Canadian Public Policy /Analyse De Politiques, 19(3), 232-251.

Glaser-Kohler, K. \& Betancourt, A. (1989). Feasibility study of archeological development to stimulate tourism: Site identification, infrastructure needs and investment requirements. Placerville, CA: RDA International.
Gordon, A. J. (2000). Cultural identity and illness: Fulani views. Culture, Medicine, and Psychiatry, 24(3), 297330.

Gordon, A. J. (2017). Agents of change in Bullet Tree Falls: How a village in Belize responded to influences of globalization. Boston, MA: Cengage Learning.

Grant, C. H. (1976). The making of modern Belize: Politics, society, and British colonialism in Central America. Cambridge, UK: Cambridge University Press.

Gregory, J. R. (1987). Men, women, and modernization in a Mayan community. Belizean Studies, 15(3), 3-21.

Harrison, D. (2001). Sustainable tourism development in the Caribbean: Practical challenges. International Journal of Contemporary Hospitality Management, 15(5), 294298.

Laidlaw, A. (1971). The man from Margaree: Writings and speeches of M. M. Coady. Toronto, Canada: McClelland \& Stewart.

Lambert, D. H., \& Arnason, J. T. (1982). Traditional milpa agriculture in Belize. Ottawa, Canada: Institute for International Development and Co-operation.

Landry, J. (1988) Final evaluation report on the education and training plan for agricultural cooperatives in Belize (1984-1987). Antigonish, Nova Scotia: St. Francis Xavier University.

Lewellen, T. (1993). Individualism and hierarchy: A grid/group analysis of American political culture. PoLAR: Political and Legal Anthropology Review, 16(3), 39-48.

Lisbey, J. (2008). Reorganization and strengthening of the Department of co-operatives. Cayo, Belize: Belize FAO Project.

Lyotard, J. F. (1984) The postmodern condition: A report on knowledge. Minneapolis, MN: University of Minnesota Press.

MacAndrew, C., \& Edgerton, R. B. (1969). Drunken comportment: A social explanation. Chicago, IL: Aldine.

Modeste, N. (1994). The impact of growth in the tourism sector on economic development: The experience of selected Caribbean countries. XXVI Annual Conference of the Regional Programme of Monetary Studies, 375386

Moore, K., \& Stanley, E. (2004). Traditions and cultural heritage of Cayo farmers. Bullet Tree Falls, Belize: MS.

Nutini, H. G. (1976). Introduction: The nature and treatment of kinship in Mesoamerica. In H. G. Nutini, P. C. Pizana, \& J. M. Taggart (Eds.), Essays on Mexican kinship (pp. 3-27). Pittsburgh, PA: University of Pittsburgh Press.

People's United Party. (1979). Manifesto for the New and Progressive Revolution. Belize City, Belize: People's United Party.

Pye, L. W. (1991). Political culture revisited. Political Psychology, 12(3), 487-508.

Quinn, N. (2003). How to reconstruct schemas people share from what they say. In N. Quinn (Ed.), Finding culture in talk: A collection of methods (pp. 35-38). New York, NY: Palgrave.

Reina. R. E. (1967). Milpas and milperos: Implications for prehistoric times. American Anthropologist, 99(1), 1-20. 
Roessingh, C., Duijnhoven, H., \& Berendse, M. (2008). Caribbean delight: Moving beyond the sustainability discourse in tourism. Revista ARA, 1(2), 21-33.

Rosberg, M. (2005). The power of greed: Collective action in international development. Alberta, Canada: The University of Alberta Press.

Rudner, M. (1991). Canada's official development assistance strategy: Process, goals and priorities. Canadian Journal of Development Studies, 12(1), 9-37.

Rugely, T. (2009) Rebellion now and forever. Palo Alto, CA: Stanford University Press.

San Miguel. (1983). ler Laboratorio experimental Yo Sayab para la formación de cuadros organizadores de cooperativas. Cooperativa San Miguel. Cayo. Belize: Bullet Tree Falls.

Savoie, D. (1994). Thatcher, Reagan, Mulroney: In search of a new bureaucracy. Pittsburgh, PA: University of Pittsburgh Press.

Shaffer, J. (1999). Historical dictionary of the cooperative movement. Lanham, MD: The Scarecrow Press.

Shoman, A. (1979). The birth of the nationalist movement in Belize 1950-1954. BISRA Occasional Publication, 7, 38-93.
Shoman, A. (2000). Thirteen chapters of a history of Belize. Belize City, Belize: The Angelus Press.

Smith, G. (2011). George Price: A life revealed-the authorized biography. Kingston, Jamaica: Ian Randle.

Strauss, C. (1992). Models and motives. In R. D'Andrade \& C. Strauss (Eds.), Human motives and cultural models (pp. 1-20). Cambridge, UK: Cambridge University Press.

Sullivan, P. (1978). Land, prestige and conflict in a Belizean village. Baltimore, MD: John Hopkins University Press.

Sutherland, A. (1998). The making of Belize: Globalization in the margins. Westport, CT: Bergin \& Harvey.

Taras, D. (1985). Brian Mulroney's foreign policy. The Round Table, 293, 35-46.

United States. (1967). A report for the subcommittee on international finance of the committee on banking and currency. Washington, DC: US Government Printing Office.

Wasserstrom, R. (1985). Grassroots development in Latin America and the Caribbean: Oral histories of social change. New York, NY: Praeger.

Zappino, V. (2005). Caribbean tourism and development: An overview. European Center for Economic Development Policy Management, 65, 20-32. 